\title{
ECDYSTERONE FROM Serratula sogdiana
}

I. L. Zatsny, M. B. Gorovits,

UDC $547.926: 591.147$

and N.K. Abubakirov

The inflorescences of Serratula sogdiana Bge., family Compositae, collected in the Shakhimardan region of the Fergana oblast in June, 1970 were extracted with hot ethanol. According to thin-layer chromatography [silica gel, chloroform - ethanol $(4: 1)$ system], the extract contained at least five phytoecdysones, with $R_{f} 0.16,0.31,0.40,0.60$, and 0.81 .

When the ethanolic extract was chromatographed on a column of silica gel in the chloroform -ethanol (9:1) system, compound (I), $\mathrm{C}_{27} \mathrm{H}_{44} \mathrm{O}_{7}$, was isolated (with a yield of $0.52 \%$ ); it had mp $242-244^{\circ} \mathrm{C}$ (anhydrous acetone), $[\alpha]_{\mathrm{D}}+59.8^{\circ}\left(\mathrm{c} 1.31 ; \mathrm{CH}_{3} \mathrm{OH}\right), \mathrm{R}_{f} 0.55-0.60 \lambda \max _{2}^{\mathrm{C}_{2} \mathrm{H}_{5} \mathrm{OH}} 246 \mathrm{~nm}(\log \varepsilon 4.40), \nu \underset{\max }{\mathrm{KBr}} 3330-3470(\mathrm{OH})$, $1650\left(\mathrm{COCH}=\mathrm{C}: \mathrm{cm}^{-1}\right.$.

The mass spectrum of (I) $\left(170^{\circ} \mathrm{C}, 40 \mathrm{~V}\right.$ ) lacked a molecular peak with $\mathrm{m} / \mathrm{e} 480$, but had peaks with $\mathrm{m} / \mathrm{e}$ $462,444,426,411,408,393,375,363,358,352,345,344,328,327,320,301,300$ and with $\mathrm{m} / \mathrm{e} 99$, 81, which corresponds to the fragmentation of ecdysterone - an insect-molting hormone [1-4]。

The nature of the optical rotatory dispersion curve, having a positive Cotton effect with an amplitude of $[\alpha]_{357}+91.5^{\circ}\left(\mathrm{CH}_{3} \mathrm{OH}\right)$ corresponds to the cis-A/B linkage of $14 \alpha-$ hydroxy-7-en-6-one compounds of the ecdysone series [5].

Compound (I) was acetylated with acetic anhydride in pyridine $\left(40^{\circ} \mathrm{C}, 4 \mathrm{~h}\right)$. The reaction product was separated on a column of silica gel. Elution with chloroform and with chloroform - ethanol (19:1) gave a

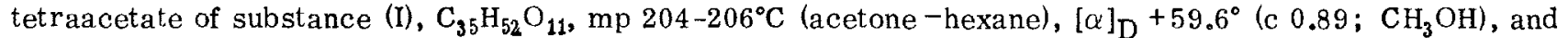
a triacetate $\mathrm{C}_{33} \mathrm{H}_{50} \mathrm{O}_{10}$ with $\mathrm{mp} 196-198^{\circ} \mathrm{C}$ (ether), $[\alpha]_{\mathrm{D}}+57.7^{\circ}$ (c $0.75 ; \mathrm{CH}_{3} \mathrm{OH}$ ) [2]. When (I) was treated with anhydrous acetone in the presence of phosphatomolybdic acid (room temperature, $2 \mathrm{~h}$ ), with subsequent separation in a thin layer of silica gel in the chloroform-ethanol (19:1) system, a diacetonide of $(\mathrm{I}), \mathrm{C}_{33} \mathrm{H}_{52} \mathrm{O}_{7}$, was obtained with $\mathrm{mp} 232-233.5^{\circ} \mathrm{C}$ (ether-hexane), $[\alpha]_{\mathrm{D}}+40.5$ (c $\left.0.88: \mathrm{CH}_{3} \mathrm{OH}\right)$ [2]。

The identity of (I) with ecdysterone was also confirmed by its NMR spectra $\left(C_{5} D_{5} \mathrm{~N}\right.$ at $100 \mathrm{MHz}$ with HMDS as internal standard, $\delta$ scale $)-0.95\left(3 \mathrm{H}\right.$ at $\left.\mathrm{C}_{19}, \mathrm{~s}\right), 1.08\left(3 \mathrm{H}\right.$ at $\left.\mathrm{C}_{18}, \mathrm{~s}\right), 1.45\left(3 \mathrm{H}\right.$ at $\left.\mathrm{C}_{21}, \mathrm{~s}\right), 1.26(6 \mathrm{H}$ at $\mathrm{C}_{26}$ and $\left.\mathrm{C}_{27}, \mathrm{~s}\right), 6.07\left(\mathrm{H}\right.$ at $\left.\mathrm{C}_{7}\right)-$ and of its triacetate $\left(\mathrm{C} \mathrm{DCl}_{3}\right)-0.80\left(3 \mathrm{H}\right.$ at $\left.\mathrm{C}_{18}, \mathrm{~s}\right), 0.98\left(3 \mathrm{H}\right.$ at $\left.\mathrm{C}_{19}, \mathrm{~s}\right), 1.21$ $\left(3 \mathrm{H}\right.$ at $\left.\mathrm{C}_{21}, \mathrm{~s}\right), 1.14\left(3 \mathrm{H}\right.$ at $\left.\mathrm{C}_{26}, \mathrm{~s}\right), 1.17\left(3 \mathrm{H}\right.$ at $\left.\mathrm{C}_{27}, \mathrm{~s}\right)$, and $5.80\left(\mathrm{H}\right.$ at $\left.\mathrm{C}_{7}\right)[2,3,6]$.

\section{LIT ERAT URE CITED}

1. H. Hoffmeister and H. F. Grütsmacher, Tetrahedron Lett., 1966, 4017.

2. M. N. Galbraith and D.H. S. Horn, Aust. Jo Chem., 22, 1045 (1969)。

3. Ya. K. Yatsyuk and G. M. Segal', Khim. Prirodn.Soedin., 6, 281 (1970)。

4. B. Z. Usmanov, M. B. Gorovits, and N. K. Abubakirov, Khim. Prirodn。Soedin., 7, 535 (1971).

5. K. Nakanishi, M. Koreeda, M. L. Chang, and H. Y. Hsu, Tetrahedron Lett. $1968,1105$.

6. T. Takemoto, Y. Hikino, K. Nomoto, and H. Hikino, Tetrahedron Lett., 1967, 3191.

Institute of the Chemistry of Plant Substances, Academy of Sciences of the Uzbek SSR. Translated from Khimiya Prirodnykh Soedinenii, No.6, pp. 840-841, November-December, 1971. Original article submitted June 18, 1971.

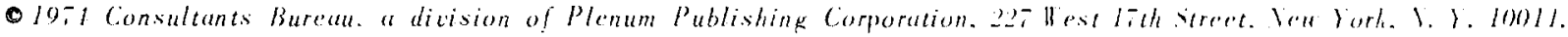
Va part of this publication ma be reproduced. stored in a retriecal system. or transmitted. in ant form or bs anv means. deetronic. mechanical, photocopving microfilming, recording or otheruise without uritten permission of the publisther. 1 coply of this article is acalable from the publisher for sion. 